\section{Public Health and Welfare.}

THE forty-eighth Annual Report of the Local Government Board, containing the report of the Medical Department for $1918-19$, is noteworthy in many respects. It is the last of what may justly be called a famous series; it is addressed, not, like its predecessors, to the President of the Board, but to the Minister of Health, and its introduction is written by the First Medical Officer of the Ministry of Health. Its contents are noteworthy too, dealing with matters that no one probably even ten years ago would have dreamed of seeing referred to in the Board's report, and with subjects that the early Medical Officers of the Board never thought of in relation to the work of the Board.

The introduction, written by Sir George Newman, takes the form of an interesting little historical note on the origin and growth of the Medical Department of the Local Government Board. To Sir John Simon, who was the first Medical Officer, to Dr. Seaton, who succeeded him, to Sir George Buchanan, to Sir Richard Thorne Thorne, to Sir William Power, and to Sir Arthur Newsholme, the last of the famous line, he pays due tribute. They were all great men in the eyes of the Public Health Service, but Sir John Simon was the greatest of them all. As the English Parliament is the mother of Parliaments, so English public health is the mother of all public health, and this is due almost entirely to Sir John Simon. That the English public health organisation is what it is to-day, the finest in the world and adopted as the model by every civilised nation, is largely thanks to him. This Sir George Newman acknowledges. He recognises also the greatness of the task before the new Ministry, and admits, though many hard things have been said of it, that the Local Government Board did work of tremendous value to the country and the people, and, "with all its limitations of machinery, proved itself a body in search of truth and having humanitarian ends." One precious possession it gave was the gift of method-"a method formulated by practice and experience, which consists of a combination of scientific work and common-sense administration, both associated with a wide and comprehensive vision." As to the future medical plans of the Ministry Sir George Newman has little to say except that steps have been taken to reorganise the medical arrangements by enlarging the staff and differentiating its functions. For the report itself Dr. G. S. Buchanan, Dr. R. J. Reece, and the Medical Inspectors of the Board are responsible, the first-named providing a general survey, as well as dealing, like each of his colleagues, with certain of the special conditions or subjects he was called upon to investigate during the year.

The bulk of the articles included relate to epidemic disease, and the outstanding feature of the year in this connection having been the pandemic of influenza, not unnaturally much space is devoted to this disease, the duty of reporting upon it being imposed upon Dr. Carnwath, who acted as secretary of the special committee set up to investigate the subject. This report contains an admirable and concise description of the outbreaks experienced here, and contains much most useful information with regard to the natural historv of the disease. Reference is made to a number of investigations, bacteriological and epidemiolosical, carried out in various parts of the country during the epidemic. So far as the former are concerned, it cannot, as Dr. Carnwath states, "yet be stated that unequivocal conclusions have been reached." Serious doubt, however, was cast upon the claims of the bacillus of Pfeiffer, which for years had been held to be the causative organism, to continue to be so NO. 263 I, VOL. IO5] regarded. So far as epidemiological investigations were concerned, attention is directed to those carried out in Leicester by Dr. Arnold, one of the Medical Inspectors, and in certain public schools by. Dr. Macewen, also a Medical Inspector. In Leicester Dr. Arnold made more or less of a general inquiry with the view of eliciting information as to age incidence, while in the schools Dr. Macewen went into the question of immunity in influenza. Neither investigator appeared to succeed in obtaining any information of practical value.

For a section of the report dealing with epidemic diseases associated specially with war conditions Dr. Buchanan is responsible; while Dr. Reece and Dr. MacNalty treat of encephalitis lethargica, the condition which the Press at first insisted upon regarding as botulism, and now persistently and, for some reason or other, jocularly refers to as "sleeping sickness." Of the war-diseases those specially dealt with are typhus and trench fever, malaria and dysentery. The fact that the first two are louse-borne diseases is stressed, and in regard to malaria it is pointed out that, though a few cases of indigenous origin have been brought to light, only in Kent was there any considerable spread of the disease. In the report on encephalitis lethargica Dr. Reece deals with prevalence, and Dr. MacNalty with the general features, of the disease. By both observers a number of references are made to instances of multiple cases in families and institutions, but both quite definitely hesitate to class the condition as infective. Dr. MacNalty's explanation of the sporadic distribution, that it belongs to the group of maladies, including such conditions as cerebrospinal fever (spotted fever) and acute poliomyelitis (infantile paralysis), in which the agent is present commonly in the body and inactive until immunity breaks down, is one likely to be generally accepted.

Apart from reports upon diseases, there are some others dealing with more oseneral matters. Of these, two calling for special reference are that by Dr. Wheaton on maternity and child welfare, and that on the work of the inspectors of food by Dr. MacFadden. Both chronicle advances and improvements. Dr. Wheaton shows that there is a steady increase in enthusiasm for welfare work amongst local authorities, as evidenced by the appointment of more and more health visitors and by the establishment of more and more centres, consultations, crèches, and day nurseries. The work of the food inspectors on behalf of the Army and the people, Dr. MacFadden states, was carried out with great activity, and, if it did nothing more, showed many openings for reforms. Of two important, long-overdue reforms, one has relation to the inspection of home-killed meat, which is inadequately done, because only just over a hundred local authorities have established public abattoirs, and much slaughtering is still done in private slaughterhouses. The other matter calling for attention is the supervision of places where food is prepared or stored. In most districts there are many places in which food is dealt with where the conditions are undoubtedly very bad. From time to time such places are discovered and efforts made to deal with them, but, as Dr. MacFadden shows, proper supervision is impossible for the reason that the powers granted by the Health Acts are inadequate and unsuitable for controlling them, and, more important still, the local inspectors are too few in number and too much overloaded with work of other kinds.

The whole report is exceedingly interesting, and in no sense inferior to those of former years. As it was the last of the series, no doubt those responsible for it desired to see it maintain the high level of excellence already attained, and they have succeeded. 